\begin{tabular}{|l|l|l||}
\hline \multicolumn{2}{|c|}{ PublisherInfo } \\
\hline \hline PublisherName & $:$ & BioMed Central \\
\hline \hline PublisherLocation & $:$ & London \\
\hline \hline PublisherImprintName & $:$ & BioMed Central \\
\hline \hline
\end{tabular}

\title{
Second-generation microarrays
}

\begin{tabular}{|l|l|l||}
\hline \multicolumn{2}{|c|}{ ArticleInfo } \\
\hline \hline ArticleID & $:$ & 4047 \\
\hline \hline ArticleDOI & $:$ & $10.1186 /$ gb-spotlight-20010411-01 \\
\hline \hline ArticleCitationID & $:$ & spotlight-20010411-01 \\
\hline \hline ArticleSequenceNumber & $:$ & 118 \\
\hline \hline ArticleCategory & $:$ & Research news \\
\hline \hline ArticleFirstPage & $:$ & 1 \\
\hline \hline ArticleLastPage & $:$ & 2 \\
\hline \hline & & RegistrationDate : 2001-04-11 \\
ArticleHistory & $:$ & OnlineDate $\quad$ 2001-04-11 \\
\hline \hline ArticleCopyright & $:$ & BioMed Central Ltd2001 \\
\hline \hline ArticleGrants & $:$ & \\
\hline \hline ArticleContext & $:$ & 130592211 \\
\hline \hline
\end{tabular}




\section{Jonathan B Weitzman}

Email: jonathanweitzman@hotmail.com

Current microarray analysis uses 'chips' containing either 25-residue oligonucleotides synthesized by photolithography or cDNAs placed by robotic spotting. In the April Nature Biotechnology, Hughes et al. describe a microarray technique that exploits an ink-jet printing method and standard phosphoramidite chemistry (Nature Biotechnology 2001, 19:342-347). The ink-jet synthesizer can deliver 25,000 phosphoramidite-containing microdroplets to a $25 \times 75 \mathrm{~mm}$ glass slide. Hughes et al. examined a large range of parameters to define conditions for optimized specificity and sensitivity. They found that 60-mer oligonucleotides hybridized at 30-32\% formamide gave the best results. The absolute detection limit was approximately 0.1 copies per cell equivalent. The ink-jet arrays were as effective as spotted cDNA microarrays. Moreover, Hughes et al. report that single carefully chosen 60-mer oligonucleotides can be preferable to arrays containing multiple oligonucleotides or cDNAs as they offer maximal specificity. The ink-jet technology provides a very flexible microarray system that can be experimentally optimized to detect low abundance mRNAs and spliced variants.

\section{References}

1. Expression monitoring by hybridization to high-density oligonucleotide arrays.

2. Quantitative monitoring of gene expression patterns with a complementary DNA microarray.

3. Nature Biotechnology, [http://biotech.nature.com]

4. Experimental annotation of the human genome using microarray technology.

This PDF file was created after publication. 